\title{
Retraction
}

\section{Retracted: Multi-Agent Systems in Control Engineering: A Survey}

\section{Journal of Control Science and Engineering}

Received 25 November 2009; Accepted 25 November 2009

Copyright (C) 2009 Journal of Control Science and Engineering. This is an open access article distributed under the Creative Commons Attribution License, which permits unrestricted use, distribution, and reproduction in any medium, provided the original work is properly cited.

This article has been retracted as it is found to contain a substantial amount of material, while without referencing, from the two papers which are:

"Multi-Agent Systems for Power Engineering Applications-Part I: Concepts, Approaches, and Technical Challenges," McArthur, S. D. J.; Davidson, E. M.; Catterson, V. M.; Dimeas, A. L.; Hatziargyriou, N. D.; Ponci, F.; Funabashi, T., IEEE Transactions on Power Systems, Vol. 22, no. 4, pp. 17431752, Nov. 2007.

"Multi-Agent Systems for Power Engineering Applications-Part II: Technologies, Standards, and Tools for Building Multi-agent Systems," McArthur, S. D. J.; Davidson, E. M.; Catterson, V. M.; Dimeas, A. L.; Hatziargyriou, N. D.; Ponci, F.; Funabashi, T., IEEE Transactions on Power Systems, Vol. 22, no. 4, pp. 1753-1759, Nov. 2007 [1].

\section{References}

[1] F. Daneshfar and H. Bevrani, "Multi-agent systems in control engineering: a survey," Journal of Control Science and Engineering, vol. 2009, Article ID 531080, 12 pages, 2009. 